\title{
Atmospheric precipitation is an ecological aspect of climate change
}

\author{
Svetlana Turko* and Karine Trubakova \\ Federal Scientific Centre of Agroecology, Complex Melioration and Protective Afforestation of the \\ Russian Academy of Sciences, Universitetskiy ave. 97, Volgograd 400062, Russia
}

\begin{abstract}
The amount of precipitation forms a varied climate type in various zones of the earth's surface. The purpose of the research is the consideration of the cause, nature, as well as the long-term forecast of precipitation as one of the environmental aspects affecting climate change. Modern analysis determined the factors affecting the distribution of precipitation on the surface of the Earth within the borders of the Volgograd region. Literary materials, data of meteorological stations, research results and observations were used. As a result of the work, the regularity of the cyclicity of precipitation was established on the basis of perennial observations by meteorological stations and is given by the forecast forecast algorithm for the prospect. Several characteristic areas on the trend were identified: periods from 1955 to 1973 (transition cycle), from 1910 to 1951 and from 1973 to 2008 (sharply pronounced cyclic precipitation processes). The main reasons affecting precipitation are determined, this is the state of the lower layers of the atmosphere and the location of the territory Analysis of the trend of falling precipitation indicates the presence of synchronization, periodicity and cyclicity of processes. The forecast of precipitation allows you to simulate river regimes, including the risks of floods, minimizing social and economic losses.
\end{abstract}

\section{Introduction}

The total annual amount of precipitation, the time and dynamics of their loss significantly affects many natural processes, including river mode, erosion processes [1, 2]. Atmospheric precipitates falling on the ground surface are the main source of moisture for drain and evaporation. Therefore, a lot of attention has always been drawn to the issue of their assessment. Now a fairly large scientific material is accumulated about the water vapor transitions in a liquid or solid state, about the formation of the weather, the transfer of the substance through the movable cloud systems. In general, the atmosphere is represented as a giant thermal machine, resulting in the radiant energy (radiation) of the Sun. The movement of the air masses is caused by various heating of individual sections of the Earth and the precipice of the atmospheric pressure. It is this, according to today's ideas, causes the air to move from some areas to others, and ultimately determines the circulation of the

\footnotetext{
*Corresponding author: turkosvetlana73@mail.ru
} 
Earth's atmosphere, which plays a dominant role in the distribution of precipitation on Earth. Currently, the climate is considered not only as a natural component of the role of the environment, but also as a component of the biological, economic and social subsystems responding to the impact of the climate. The amount of precipitation forms a different type of climate in various zones of the Earth's surface [3, 4].

\section{Materials and methods}

The authors reviewed the causes, character, as well as a long-term forecast of precipitation, as one of the factors affecting the river regime in the Volgograd region. We used the materials of meteorological stations, literature data, the results of observations at the hydrological complex of the Federal Research Center for Agroecology of the Russian Academy of Sciences (Volgograd). When processing materials, a package of standard statistical programs was used.

\section{Results and discussion}

When studying the distribution of precipitation, it was revealed that it is uneven. The circle of factors affecting the quantitative characteristics is determined. Moreover, the factors themselves are due to their nature. No exception and solar radiation coming to the earth's surface [5-8]. Here, one of the causes of the variation is the dynamics of the gas structure of the earth's atmosphere. Another reason is that the surface of the sushi and water bodies have different thermal properties. The latitude of the terrain plays a certain role. The variation of solar radiation is the greater, the smaller the value of the latitude $(\varphi)$. In other words, at the equator this variation is more.

Mathematically, this for medium perennial radiation values can be expressed as follows:

$$
q_{\phi}=q_{e}\left[\frac{1}{1+2.615 e^{-\lambda(90-\phi)}}\right], \lambda=\left(0.062 \cdot 10^{-3 \phi}\right)
$$

$q_{\mathrm{e}}$ - the arrival of total solar radiation at the Earth's equator and on its separate latitudes; $\varphi$ - the latitude of the area; $\lambda$ - Light wavelength.

If, as a basis for estimating the degree of variation of solar radiation in the latitude function $\varphi$, take a standard deviation $(\delta)$, then it can be noted that the latter with an increase in values $\varphi$ decreases.

Mathematically, this can be expressed as follows:

$$
\delta_{\phi}=\delta_{e}-0.17 \cdot 10^{-2} \phi^{2}
$$

$\delta_{e}-$ standard deviation at $\varphi=0$; - latitude of terrain, hail.

With solar radiation, the air temperature in the surface layer of the troposphere, and, consequently, the circulation processes of the air mass [9] should be closely connected. The temperature of the latitudinal circle (the average temperature in latitude) changes according to the parabolic law in the latitude function $(\varphi)$. Like solar radiation, the air temperature of the lower layers of the troposphere is also not unambiguous, but in a certain way varies. Moreover, this variation is also the greatest of the equator and with increasing $\varphi$ decreases. 


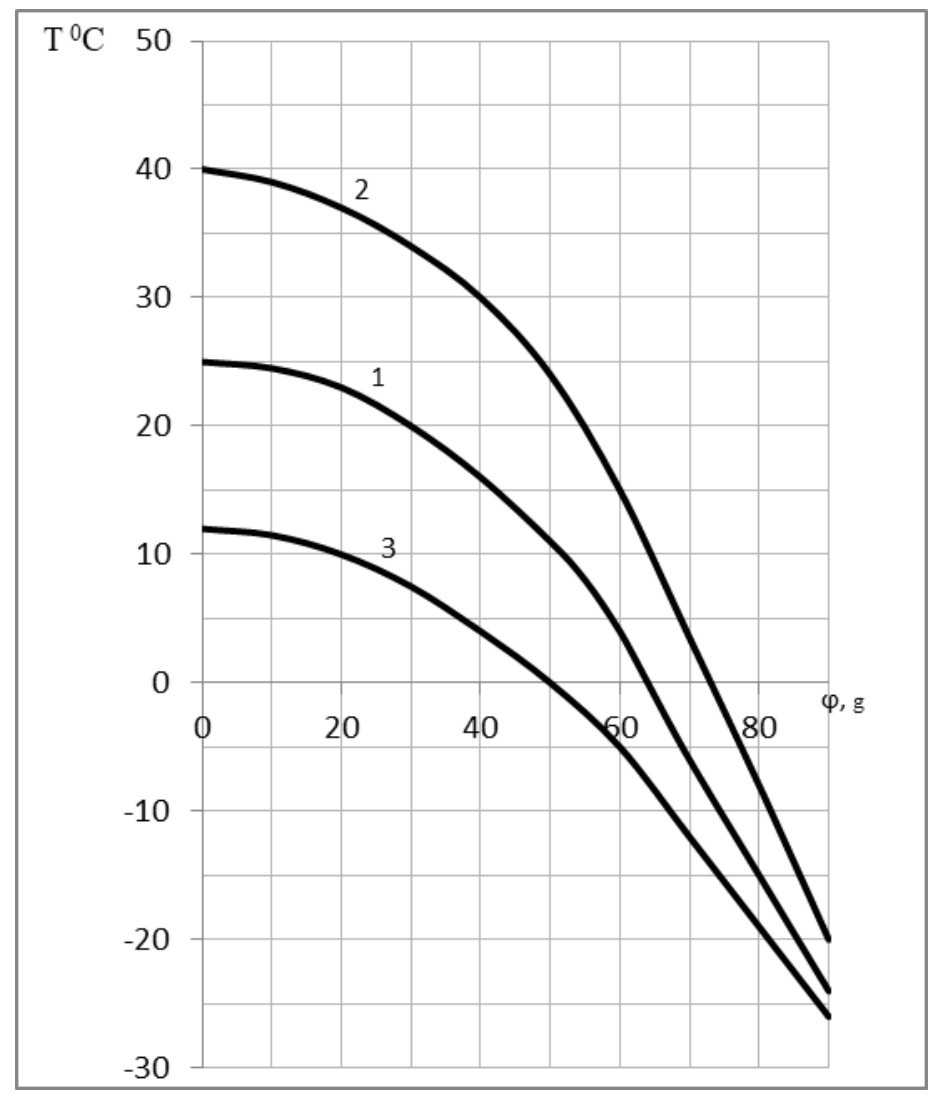

Fig. 1. Changing values of the average annual air temperatures (1) and their variations in the surface layer of troposphere $(2,3)$ in the latitude function.

The reasons affecting the nature of the movement of air masses could be in another circumstance. Since the earth has a magnetic field and is a giant "dynamo machine", and the position of the poles in the temporary aspect is not constant [10], we can assume that if the configuration of the magnetic field of the Earth changes, then changes in the nature of circulation in the lower layers of the troposphere. It is possible that this leads to a change and quantitative characteristics of precipitation in different territories of the Earth.

The nature of the circulation of the atmosphere, and, consequently, the precipitate on Earth may be associated with the inversion of the magnetic field of the Sun and its activity (Wolf numbers), which occur regularly with 11 year cycles, (or rather with cycles from 7 to 17 years) [11-13].

From all the outlined, it is an important conclusion that precipitation is determined by two main factors: the state of the lower layers of the atmosphere and the location of the territory. An important role has relief of the territory, remoteness from oceans and mountain structures, causing the formation of rising flows and forming the zonal regions on Earth. In this aspect, it is interesting to consider how precipitation in the Volgograd region has been formed in the longterm cycle with a relatively flat relief and ocean remoteness. The tendency developed by A.N. Sazhin [11].

Processed data clearly shows that several characteristic areas on the trend are distinguished. These are periods from 1955 to 1973 (transitional region), from 1910 to 1951 and from 1973 to 2008 (areas with expressly pronounced cyclic processes of precipitation) [11]. In this regard, a number of natural issues arise. Firstly, what caused such a picture of events. The above reasons for variation of precipitation do not explain it. Secondly, whether 
the identified patterns can ensure the forecast for the prospect of the speakers of annual precipitation. Thirdly, as far as the identified patterns are universal from the position of binding them to other territories of the Earth, and not only to the territory of the Volgograd region. In modern literature, there are no data explanatory phenomena. We emphasize this attention and hope that experts dealing with meteorology and climatology will try to explain from the standpoint of the Principal Laws on Earth and Sedings.

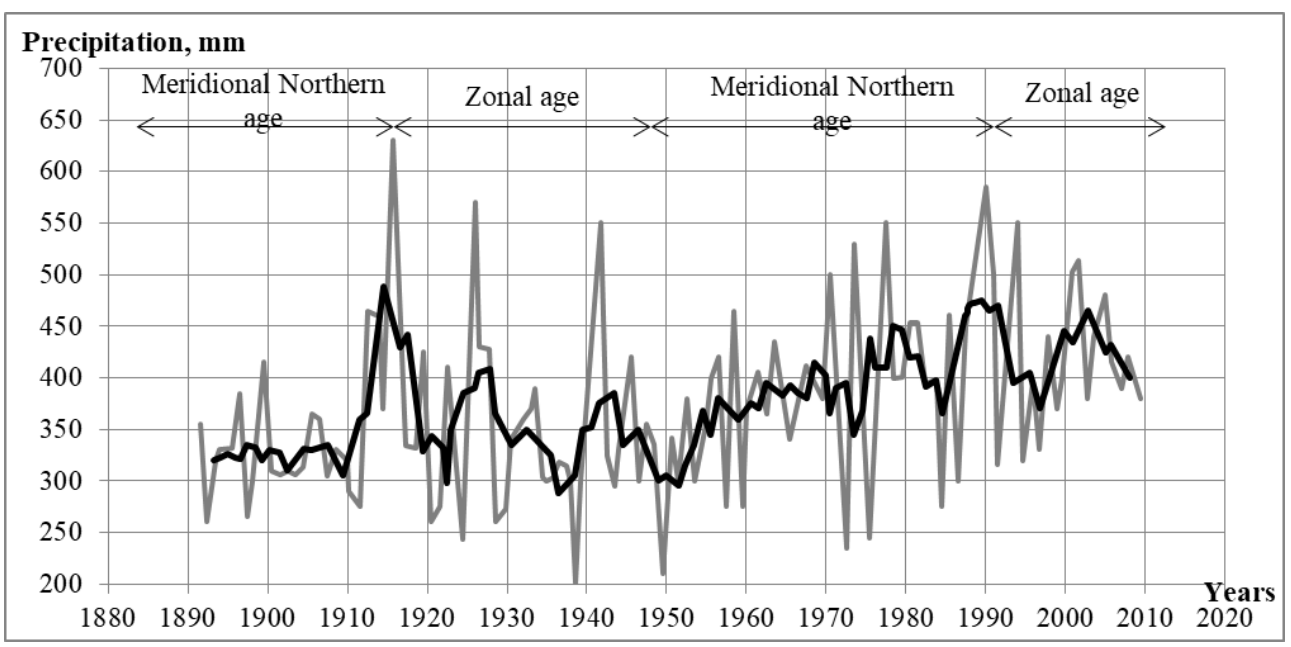

Fig. 2. The age-old course of precipitation in the Volgograd region.

From the results obtained, it follows that such a character of drop-down precipitation can affect the hydrological regime of rivers, adjusting the drains. Therefore, a long-term precipitation forecast for today is very acute. It will be important in the long run, but will require the development of certain theoretical aspects and digital technologies. There are no such technologies today. Therefore, our research goes on a simplified path. The forecast part was carried out on analog basis. It was hypothetically assumed that processes in the future would also flow synchronously, as they occur in the analyzed period. That is, it is assumed that the second cyclic area will follow the transition region, then the first cyclic region, etc.

The forecast of precipitation allows you to simulate river regimes, including the risks of floods, minimizing social and economic losses. And as it is impossible to prevent floods as a natural disaster, but it can be loosen or localized, thereby minimize social and economic losses. In addition, the amount of drop-down precipitation correlates with the intensity of erosion processes. Knowing the rhythm of precipitation, it is possible to predict an annual flush from the drain, stormwater, and measures to prevent erosion processes.

\section{Conclusion}

An analysis of perennial data of drop-down precipitation within the boundaries of the Volgograd region indicates the presence of certain, previously unknown, laws in a longterm aspect, and more precisely, the presence of a time interval, synchronicity, cyclicity of processes. It can be assumed that the same pattern may manifest itself in other territories of the Earth and may even be dependent on the latitude of the terrain. However, theoretical developments in this area of research existing today, as well as the Prophysical base, do not necessarily assert this, because they do not allow to explain the revealed phenomenon. Therefore, today, forecasts can be carried out only on a trend basis, using certain assumptions and hypotheses. At the same time, to establish the dependence of the processes 
of annual precipitation from the latitude of the territory, similar approaches are needed in precipitation calculations in other territories of the Earth.

As a result, an algorithm was developed, on the basis of which it was predicted that in the period from 2002 to 2030. An annual amount of precipitation will decline, reaching a minimum of $310-320 \mathrm{~mm}$ by 2021 . Then the stabilization period comes. Since 2030, the cyclic process of precipitation drops will be manifested when the annual amount will change under the law of the first harmony. Here, the precipitates will vary from 470 to 290 $\mathrm{mm}$.

The authors want to thank Yuri Vasiliev for the scientific and technical assistance provided throughout all the experiment.

\section{References}

1. V. N. Pavlova, O. D. Nablyudaemye izmeneniya klimata i dinamika produktivnosti sel'skogo hozyajstva Rossii Trudy GGO 565 132-151 (2012).

2. M. Yu. Bardin, O. N. Bulygina, T. V. Platova Jekstremal'nost' klimata Vtoroj ocenochnyj doklad Rosgidrometa ob izmeneniyah klimata i ih posledstviyah na territorii Rossijskoj Federacii. Moscow: Rosgidromet 171-202 (2014).

3. C. Schar, N. Ban, E. M. Fischer Percentile indices for assessing changes in heavy precipitation events Climatic Change 137 201-216 (2016).

4. J. Sillmann, T. Thorarinsdottir, N. Keenlyside Understanding, modeling and predicting weather and climate extremes: Challenges and opportunities Weather and Climate Extremes 18 65-74 (2017).

5. L. V. Alexander Global observed long-term changes in temperature and precipitation extremes: A review of progress and limitations in IPCC assessments and beyond Weather and Climate Extremes 11 4-16 (2016).

6. J. L. Catto, S Pfahl The importance of fronts for extreme precipitation J. Geophys. Res. Atmos. 118 791-801 (2013).

7. Y.Chen, P Zhai Changing structure of wet periods across southwest China during Clim. Res. 61 123-131 (2014).

8. N. Herold, L. V. Alexander, M. G. Donat, S. Contractor, A. Becker Geophys. Res. Lett. 43 341-348 DOI:10.1002/2015GL066615 (2016).

9. I. A Kulikova, E. N Kruglova, D. B.Kiktev Krupnomasshtabnye mody atmosfernoj izmenchivosti. Chast' II. Ih vliyanie na prostranstvennoe raspredelenie temperatury i osadkov na territorii severnoj Evrazii Meteorology and hydrology 4 5-16 (2015).

10. Astronomical portal "Imya Galaktiki" [Electronic resource] Access mode:www.galactic.name/articles/astronomical_lecture_0023_earth_magnetic_field.ph.

11. K. N. Kulik, A. S. Rulev, A. N Sazhin Global'nye processy deflyacii v stepnyh ekosistemah Meteorology and hydrology. 9 72-80 (2018).

12. Nauchnaya biblioteka izbrannyh estestvennonauchnyh izdanij [Electronic resource] Access mode: http://stu.alnam.ru/book_mor-39.

13. A. N. Sazhin, K. N. Kulik, Yu. I. Vasil'ev Pogoda i klimat Volgogradskoj oblasti Volgograd: VNIALMI 333 (2017). 